Horned Owl, 2; Downy Woodpecker, 1; Black-billed Magpie, 8; Blackcapped Chickadee, 14; Bohemian Waxwing, 6; House Sparrow, 1156; Common Redpoll, 119; Snow Bunting, 169. (Add: Hairy Woodpecker, 1, Dec. 28.)-Gary Anweiler, Henry Chilman,
Jr., Tom Cursons, Archie Fraser, Art Gellert, Dr. and Mrs. Stuart Houston (compilers), Dr. C. J. Houston, Stanley Houston, Phil Pawluck, Elwood Sharpe, Jeff Smith, Donald Swaby, Frank Switzer, Guillain Switzer (Yorkton Natural History Society.)

\title{
Distraction Display By Western Meadowlark
}

\author{
By Sam Alberts, Brooks, Alberta
}

I was very interested in the article in the September, 1959, issue of the Blue Jay by Robert Nero "Distraction Display by Western Meadowlark." On the evening of July 27, 1959, I drove my truck up to the edge of a field that I was starting to irrigate. I noticed a meadowlark fly up and then come down to the ground and start doing the broken wing act as it went through the grass. My first thought was that it was a young one and that I had run over it, then I noticed it fly up on to a fence post so I knew it wasn't injured. It being so late in the summer I didn't think there would be a nest. However, when the same thing happened the next day I started looking for a nest, and found that if I had driven about two feet further I would have run over it. There were three young that looked about half-grown. I drove up to the same place about a dozen times on the 28th and 29th and each time the mother bird went through the same antics. At the time it seemed rather odd to see a meadowlark doing this broken wing act, but I did not know it was such an unusual thing or I would have watched it more closely and tried to get some pictures. We left for a few days holidays on the 30 th and when I came back on August 7 the nest was empty.

Note: Readers may be interested in similar report for the Westerm
Meadowlark by J. M. Linsdale (1938. Environmental responses of vertebrates in the Great Basin. Amer. Midland Nat., 19:1-206). On page 127 Linsdale states: "A brooding bird flew up just as it was almost stepped on. It landed 2 feet away and ran, fluttering along the ground for 50 feet, disappearing beneath a clump of buffalo berry." And Du Bois, quoted by A. C. Bent (1958. Life histories of North American blackbirds, orioles, tanagers, and Allies, U.S. Nat.' Mus. Bull. 211:36) describes nearly identical behaviour for the Bobolink: "The female jumps over the grass for a distance of three or four feet, then hobbles along in the grass; and, if I follow her, she repeats this-and continues to repeat until we are perhaps a hundred feet from the nest, then she flies for a short distance. This is the pattern of her ruse." "Bent points out that one reason for the difficulty of locating Bobolink nests is the female's habit of running through the grass for some distance from the nest before flushing (loc.cit: 35 ).

It seems apparent that in these two species this type of "distraction display" provides an effective means of escape from the nest (thus saving the nest), at least in some types of cover, as well as being a ruse to lure away predators. 